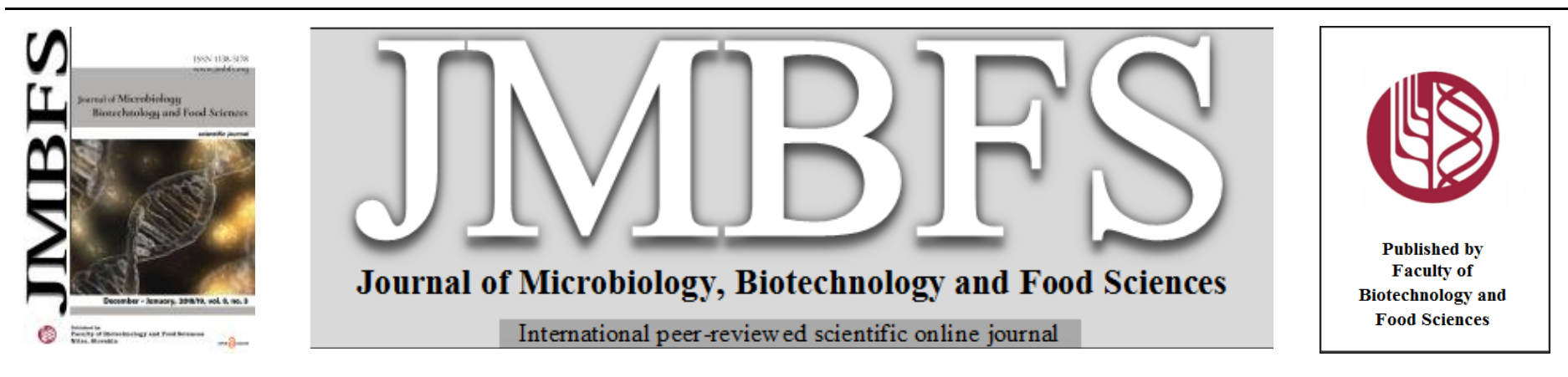

\title{
IMPACT OF PROCESSING ON PROXIMATE COMPOSITION AND MEDICINAL PROPERTIES OF MUCUNA SANJAPPAE SEEDS: A FUNCTIONAL FOOD
}

\author{
Ravishankar Patil ${ }^{1,3,4}$, Govind Vyavahare ${ }^{l}$, Chetan Aware ${ }^{l}$, Vishwas Bapat ${ }^{l}$, Hosakatte Niranjana Murthy ${ }^{3}$, Jyoti Jadhav ${ }^{1,2 *}$
}

Address(es):

${ }^{1}$ Department of Biotechnology, Shivaji University, Vidyanagar, Kolhapur, Maharashtra, India.

${ }^{2}$ Department of Biochemistry, Shivaji University, Vidyanagar, Kolhapur, Maharashtra, India.

${ }^{3}$ Department of Botany, Karnatak University, Dharwad, Karnataka, India.

${ }^{4}$ Amity Institute of Biotechnology, Amity University, Panvel, Mumbai, Maharashtra, India. (Current Affiliation).

*Corresponding author: jpjbiochem@gmail.com

doi: 10.15414/jmbfs.2018-19.8.3.905-910

ARTICLE INFO

Received 4. 4. 2018

Revised 6. 6. 2018

Accepted 1. 10. 2018

Published 1. 12. 2018

Regular article

OPEN $\partial_{\text {ACCESS }}$

\begin{abstract}
Mucuna sanjappae seeds are conventionally used as food and medicine in the Western Ghats of India. It possesses good nutritional value with higher level of anti-Parkinson's drug L-DOPA $(10.81 \mathrm{~g} / 100 \mathrm{~g})$. But, presence of anti-nutritional compounds hardens its preferential use as a food of choice. In the present study, the effect of various commonly used processing methods (soaking, autoclaving, roasting, soaking plus autoclaving and soaking plus roasting) on L-DOPA, nutritional, anti-nutritional factors, antioxidant activity $(2,2$ diphenyl-1-picrylhydrazyl and ferric reducing/antioxidant power assay) and anti-inflammatory activity was determined. RP-HPLC analysis of processed MS beans showed significant reduction of L-DOPA $(\mathrm{p}<0.001)$ due to various treatments among which soaking $(2.91 \pm 0.09 \mathrm{~g} / 100 \mathrm{~g})$ and soaking plus autoclaving $(1.10 \pm 0.08 \mathrm{~g} / 100 \mathrm{~g})$ was most effective treatments. DPPH radical scavenging activity was significantly reduced after the processing treatment $(\mathrm{p}<0.001)$ and showed maximum reduction in soaking plus autoclaving process $(81.741 \pm 0.596 \%$ to $44.311 \pm 0.69 \%)$. In contrast, FRAP assay does not showed significant decrease $(\mathrm{p}>0.05)$ in activity. Antiinflammatory activity (BSA anti-denaturation assay and HRBC membrane stabilization activity) was also found to be decreasing after processing of M. sanjappae (MS) seeds $(\mathrm{p}<0.001)$. This paper has thoroughly given the effect of processing on nutritional value, antinutritional compounds, antioxidant potential and has first time reported anti-inflammatory activity of $M$. sanjappae seeds.
\end{abstract}

\section{INTRODUCTION}

Genus Mucuna is well-known for the food, feed, cover crop, medicine and ornamental purpose (Osei-Bonsu et al., 1995; Carsky et al., 1998). This marvelous herb is known by many names including sea beans, buffalo beans, dopa bean, cowitch, kapikachu and atmagupta. It comprises 100 species worldwide and is represented by ten species and four varieties from the Indian subcontinent (Wilmot-Dear 1986, 1991; Patil et al., 2015). These species are rare and mostly found in the specific forest region of the India. The seeds of Mucuna contains L-DOPA (L-3, 4-dihydroxyphenylalanine), a promising drug for Parkinson's disease management. These seeds are also widely used against snakebite, uterine stimulant and as an aphrodisiac in traditional system of medicine predominantly in India and West Africa (Patil et al., 2015) Unfortunately, Mucuna species other than M. pruriens has remained underutilized and neglected for their possible use in food and drug (Patil $\boldsymbol{e t}$ al., 2015). It is observed that, regardless of any scientific knowledge, Indian ethnic people are continuously using such species as a staple food and for the cure of different disease including Parkinson's disease and male infertility (Patil et al., 2015; Lampariello et al., 2012). These people have experience based theories about the numerous valuable properties of such plants.

M. sanjappae (MS) is a species of Mucuna described from the Junner area of Western Ghats, India (Aitawade and Yadav, 2012). A single pod of $M$. sanjappae contains 5-6 brown and black seeds (Aitawade and Yadav, 2012) having potential nutritional value with gross energy $383 \mathrm{kcal}$ (Patil et al., 2015). But, as found in other legume seeds, it also contains anti-nutritional factors including phenolics, phytic acid, saponin, tannin, etc. Such anti-nutritional factors have adverse physiological effects which harden the use of $M$. sanjappae as a daily food of choice. Though L-DOPA has immense value in the Parkinson's disease treatment, its regular consumption has several anti-metabolic effects like acidity, nausea, and vomiting. Phytic acid and polyphenol decrease digestibility and utilization of legume protein and starch (Nielsen, 1991; Liener, 1994; Bishnoi et al., 1994; Siddhuraju and Becker, 2005; Khattab and Arntfield,
2009). Despite their moderately high amount of protein, calories, vitamins and minerals; their usage in food and feed becomes limited by the presence of antinutritional factors (ANFs) (Khattab et al., 2009). These ANFs have several important functions in the growth and development of plants itself; hence to solve this issue at the genetic level could be extremely disastrous. So, it is important to overcome problem using some adequate, simple and cost effective processing techniques. Such techniques can reduce or completely remove the ANFs from legumes for better consumption by human as well as animals (Khattab and Arntfield, 2009).

In this connection, different pretreatments like soaking, germination, boiling, autoclaving, roasting, fermentation and advanced treatments like gamma radiation are being used for successful reduction of ANFs at a considerable level suitable for the consumption (Chau et al., 1997; Tiansawang et al., 2016). The processing methods being employed also affects the nutritional composition and other properties including antioxidant and anti-inflammatory activity of the processed food. With this background, present research work was attempted to study and compare the effects of various processing methods on the L-DOPA, nutritional-antinutritional composition and antioxidant activity of $M$. sanjappae beans.

\section{MATERIALS AND METHODS}

\section{Collection of plant material}

MS seeds were collected from Junner area of Maharashtra, India and stored at room temperature in a polyethylene bag $\left(25 \pm 2^{\circ} \mathrm{C}\right)$ until use. The herbarium was maintained at Department of Botany, Shivaji University, Kolhapur (Voucher IDSVG004). 


\section{Chemicals and reagents}

All the chemicals and solvents used for the experiment were of analytical grade. Folin-ciocalteu reagent, sodium carbonate, aluminium trichloride, ferric chloride, potassium acetate, ascorbic acid, 2,4,6- tripyridyl-s-triazine (TPTZ), 2,2 Diphenyl-1- picrylhydrazyl (DPPH), bovine serum albumin, diclofenac, quercetin, catechin and methanol for HPLC were obtained from Sigma Chemical Co., USA. L-DOPA, phytic acid, tannin monosodium phosphate, di monosodium phosphate was purchased from HiMedia.

\section{Processing methods}

The seeds were randomly divided into six groups (30 g/ group). The first group was kept as raw seed without any treatments. The remaining five groups were subjected to various processing methods is shown in fig 1 and briefly described below:

Process A (Soaking): MS seeds were soaked in distilled water (D/W) for $24 \mathrm{hrs}$. Process B (Autoclaving): MS seeds were autoclaved at $15 \mathrm{lb}$ pressure $\left(121^{\circ} \mathrm{C}\right)$ in $\mathrm{D} / \mathrm{W}$ for $20 \mathrm{~min}$

Process C (Roasting): MS beans were roasted on burner using the hot pan for 15 $\min$.

Process D (Soaking plus Autoclaving): MS beans were soaked in D/W for 24 hrs and then autoclaved at $15 \mathrm{lb}$ pressure $\left(121^{\circ} \mathrm{C}\right)$ for $20 \mathrm{~min}$.

Process E (Soaking plus Roasting): MS seeds were soaked in D/W for $24 \mathrm{hrs}$ and then roasted on burner using the hot pan for $15 \mathrm{~min}$.

The respective MS seed samples were dried and a fine powder was prepared using mortar pestle for further analysis.

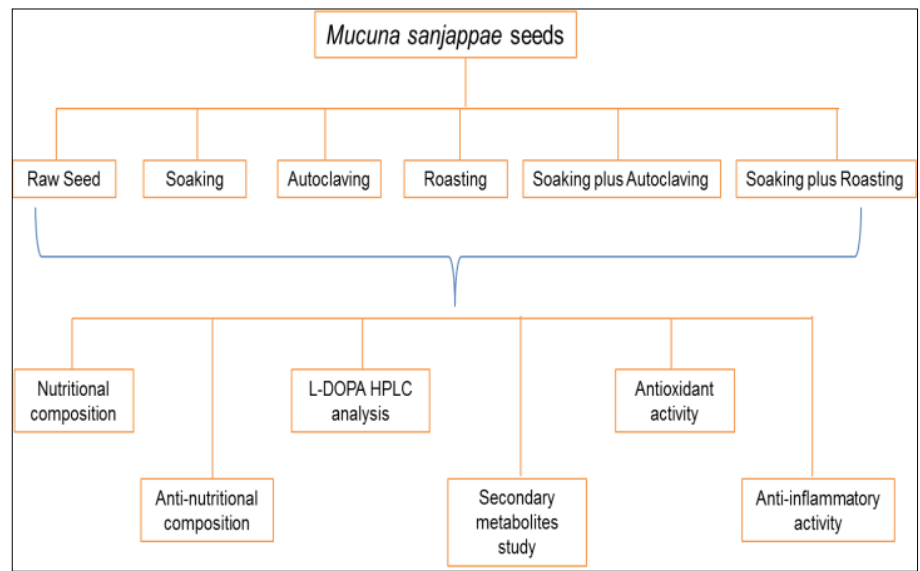

Figure 1 Schematic drawing of different processing methods and further analysis of $M$. sanjappae seeds.

\section{RP-HPLC analysis of L-DOPA}

The differentially processed seed samples were analyzed for L-DOPA using reverse phase high performance liquid chromatography (Shimadzu). Sample preparation was carried out as described by Rathod et al. (2014) with slight modifications. One gram of respective MS seed sample was extracted with methanol: $0.1 \mathrm{M} \mathrm{HCl}(70: 30)$ for $30 \mathrm{~min}$ on rotary shaker $(120 \mathrm{rpm})$ and sonicated for $5 \mathrm{~min}$. The samples then evaporated until dry, dissolved in methanol $(5 \mathrm{mg} / 10 \mathrm{ml})$ and filtered through $0.45 \mu \mathrm{m}$ nylon filter (Axiva filters). RP-HPLC analysis was carried out by Shimadzu prominence equipped with degasser DGU-20A 5R, low pressure quaternary pump LC $20 \mathrm{AD}$ and photo diode array detector SPD- M20 A. Chromatographic separation was achieved on a Waters, Nova-Pak C18 column $(4 \mu \mathrm{m}, 4.6 \times 250 \mathrm{~mm})$. Methanol was used as a

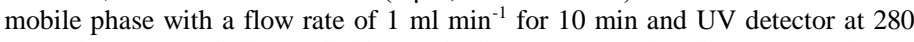
$\mathrm{nm}$. The commercially available synthetic LDOPA (Himedia) was used as a standard.

\section{Biochemical analysis sample preparation}

$200 \mathrm{mg}$ of respective seed powder was added to $10 \mathrm{ml} \mathrm{D} / \mathrm{W}$, sonicated for $5 \mathrm{~min}$, crushed using mortar pestle and then centrifuged at $10,000 \mathrm{rpm}$ for $15 \mathrm{~min}$, the supernatant was decanted, and again procedure was repeated for residue. The supernatant was pulled together and diluted to a known volume by $\mathrm{D} / \mathrm{W}$. This sample was used for biochemical analysis.

\section{Nutritional factors and secondary metabolites determination}

Total ash (AOAC, 2000), total solid (James, 1995) and crude fiber (AOAC 1990) were determined according to standard methods. The protein content was determined using Lowry's method (Lowry, 1951). The total carbohydrate content was estimated using the Anthrone reagent method (Trevelyan et al. 1952). The reducing sugar was determined using the method of (Miller, 1959) whereas; crude fat was measured by Mojonnier method (James, 1995). For the starch quantification, the processed seed flour was made sugar free using $80 \%$ ethanol. Then starch was extracted by perchloric acid reagent (McCready, 1950) and quantified colorimetrically at $630 \mathrm{~nm}$. The starch content was determined in $\mathrm{mg}$ of glucose X 0.9. The total flavonoids content was determined (Chang et al. 2002), and results were expressed as milligram of quercetin equivalents per gram (mg QUE g-1) of dry weight. The proanthocyanidin content was evaluated (Sun et al., 1998) and expressed as catechin equivalents per gram (mg CAE g-1) of dry weight.

\section{Anti-nutritional factors determination}

The spectrophotometric quantification of phytic acid was carried out (Gao, 2007). In brief, $1 \mathrm{ml}$ sample was mixed with $1 \mathrm{ml}$ of Wade reagent and solution was vortexed for 5 seconds and centrifuged for $10 \mathrm{~min}$. The supernatant was used for the measurement of absorbance at $500 \mathrm{~nm}$. The phenolic content of processed MS beans was determined spectrophotometrically (Singleton, 1965). Tannin was determined using the Folin-Denis colorimetric method (Kirk and Sawyer, 1998) while saponin was quantified according to the slandered method (Harborne, 1973).

\section{Antioxidant activity study}

\section{DPPH free radical scavenging assay}

The DPPH (2,2-diphenyl-1-picrylhydrazyl), free radical scavenging capacity of the differentially processed MS seed samples was determined according to the procedure described by Brand-Williams et al. (1995) with slight modification (Thaipong, 2006). The DPPH radical scavenging capacity was calculated in percent using the following equation:

$$
\% \mathrm{RSC}=\mathrm{A}_{(\text {control })}-\mathrm{A}_{(\text {(sample) }} / \mathrm{A}_{(\text {control })} \mathrm{X} 100
$$

\section{FRAP (ferric reducing/antioxidant power) assay}

The FRAP assay was performed to determine the antioxidant capacity of differentially processed MS samples (Benzie $\boldsymbol{e t}$ al., 1996). The absorbance of the ferrous tripyridyltriazine complex product was measured at $593 \mathrm{~nm}$ using a UVvisible spectrophotometer. A higher absorbance reading revealed a higher reducing power.

\section{In vitro anti-inflammatory activity}

Sample was prepared by adding $100 \mathrm{mg}$ MS seed powder in $10 \mathrm{ml} \mathrm{D} / \mathrm{W}$ and extracted in mortar pestle. The extracted sample was then centrifuged at 10000 $\mathrm{rpm}$ for $10 \mathrm{~min}$ and supernatant was collected. Effective yield was calculated by evaporating water from extract and further diluted to known concentration for experimentation purpose.

\section{Bovine serum albumin (BSA) anti-denaturation assay}

BSA protein anti-denaturation test was achieved by method described by Grant et al., (1969) with slight modifications. In brief, different concentrations of extracted MS bean samples and standard anti-denaturation drug Diclofenac were allowed to react with $1 \mathrm{ml}$ of BSA solution (1\% BSA in $50 \mathrm{mM}$ Tris buffer, $\mathrm{pH}$ $6.5)$. The reaction was accomplished by incubating at $37^{\circ} \mathrm{C}$ for $20 \mathrm{~min}$ and then heated to $64^{\circ} \mathrm{C}$ in water bath for 5 to 10 minutes till mixture get turbid. After cooling, turbidity was measured at $660 \mathrm{~nm}$ by spectrophotometer. Control was D/W instead of test sample for the preparation of control. The denaturation inhibition percentage was calculated as follows:

$\%$ denaturation inhibition $=\mathrm{A}($ control $)-\mathrm{A}($ sample $) / \mathrm{A}($ control $)$ X 100

Where, A (control) is absorbance of the control and A (sample) is absorbance of samples.

\section{Membrane stabilization test}

Fresh whole human blood $(15 \mathrm{ml})$ was centrifuged at $3000 \mathrm{rpm}$ for $10 \mathrm{~min}$ and packed RBCs were collected. The packed RBCs were further washed for three times with equal volume of normal saline by centrifugation at $3000 \mathrm{rpm}$ for 10 min. The packed cell volume was measured and diluted as $10 \% \mathrm{v} / \mathrm{v}$ suspension using normal saline (Sadique et al., 1989).

The hypotonicity induced haemolysis assay was carried out as method described by Bhurat et al. (2011). In brief, reaction mixture containing $2 \mathrm{ml}$ hypo saline, $1 \mathrm{ml} 0.15 \mathrm{M}$ phosphate buffer ( $\mathrm{pH} 7.4), 1 \mathrm{ml} \mathrm{MS}$ extract $(200 \mu \mathrm{g}-600 \mu \mathrm{g} / \mathrm{ml})$ in isosaline and $0.5 \mathrm{ml} 10 \%$ reconstituted $\mathrm{HRBC}$ was incubated at $37{ }^{\circ} \mathrm{C}$ for $30 \mathrm{~min}$ 
and then centrifuged at $3000 \mathrm{rpm}$ for $20 \mathrm{~min}$. Distilled water used instead of hypo saline to prepare control. Hemoglobin content in the supernatant was determined spectrophotometrically at $560 \mathrm{~nm}$. Synthetic diclofenac was used as a standard drug.

Percentage stabilization: 100 - Absorbance of test / Absorbance of control X 100

\section{Statistical analysis}

All experimental analysis was carried out in triplicates and results were expressed as a mean \pm SEM value. Data were statistically studied using GraphPad Prism 5 The significant difference between means was calculated by one way analysis of variance (ANOVA) followed by Dunnett multiple range test at $\mathrm{P}<0.05$.

\section{RESULTS AND DISCUSSION}

Legumes are the low-cost source of protein, complex carbohydrate, dietary fiber and contribute significant amounts of vitamins, minerals with high energy value (Nielsen, 1991; Tharanathan and Mahadevamma, 2003). Number of leguminous species are being used for the daily food requirement, and extensive study has been carried out regarding their nutritional value (Siddhuraju and Becker, 2005; Costa et al., 2006; Mugendi et al., 2010). A well- known species of Mucuna, M. pruriens has been thoroughly investigated for its L-DOPA content, nutritional, anti-nutritional composition, in vitro protein-starch digestibility and possible use in poultry feed after domestic processing (Siddhuraju and Becker, 2001,2005; Nyirenda et al., 2003; Vadivel and Pugalenthi 2008; Mugendi et al., 2010)

There is ever increasing demand of food to the growing population of world especially in the developing countries. To fulfill the large demand of food, there is necessity of searching cheaper sources to prevent malnutrition. Numbers of leguminous species are being consumed locally as an optional food but still uninvestigated and unexplored. To this point, our laboratory is comprehensively working on such unexplored species from different leguminous genus for determining their nutritive values. Earlier we had reported nutritional and antinutritional composition of $M$. sanjappae (Patil et al., 2015). The present study was undertaken on the new leguminous species $M$. sanjappae for evaluating processing effect on L-DOPA, nutritional-antinutritional factors antioxidant potential and anti-inflammatory activity.

\section{Effect of processing on L-DOPA level}

The level of L-DOPA in the raw and processed MS seed sample was determined using RP-HPLC (Fig 2).

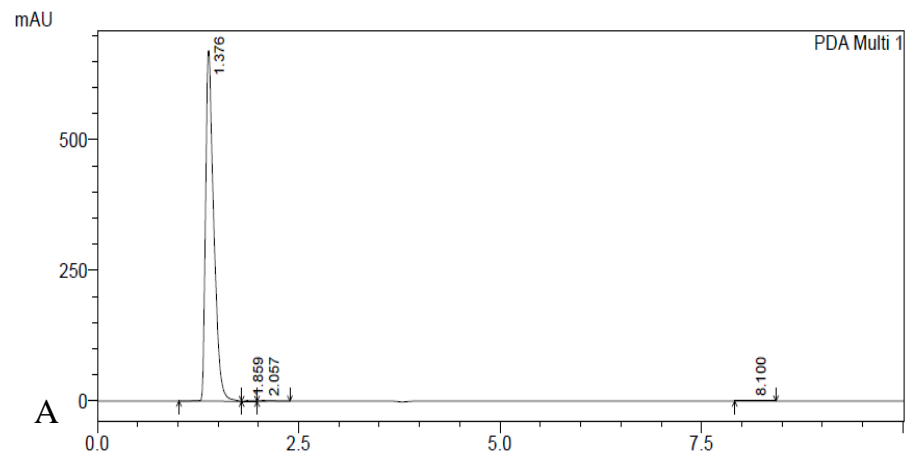

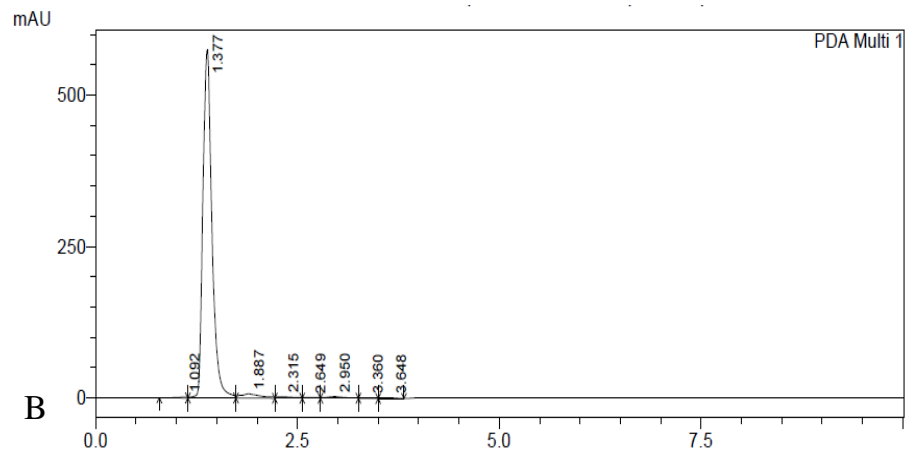

Figure 2 HPLC profile of L-DOPA. a) Standard L-DOPA b) Raw M. sanjappae bean

MS seed showed $10.814 \pm 0.242 \mathrm{~g} / 100 \mathrm{~g}$ (Fig 3 and Table 2) of L-DOPA. Earlier, we had reported $7.3 \mathrm{~g} / 100 \mathrm{~g}$ of L-DOPA with the simple extraction method using $0.1 \mathrm{~N}$ aqueous HCL (Patil et al., 2015). Seasonal variation of collected MS seeds and optimized extraction method might be the reason for the higher quantified level of L-DOPA in the sample. All the cooking processes significantly decreases $(\mathrm{p}<0.001)$ the level of DOPA content as compared to raw seed sample.

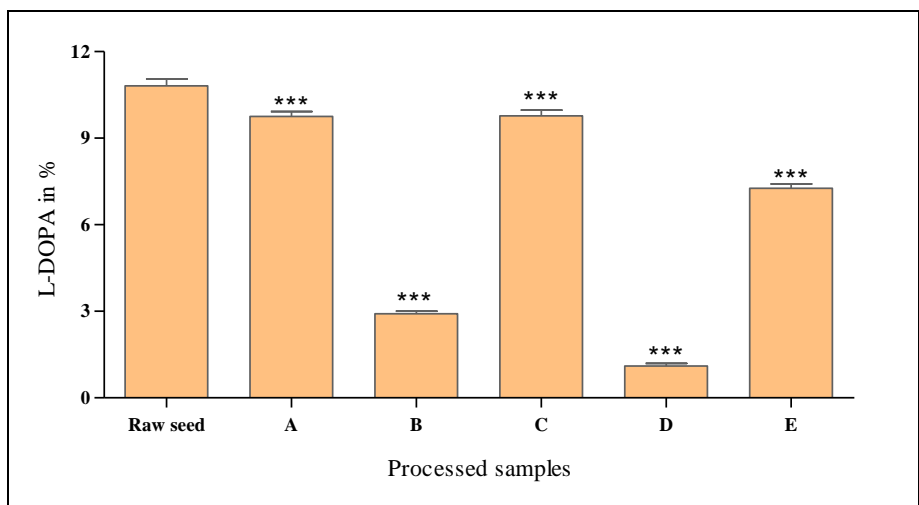

Figure 3 Effect of processing on the L-DOPA content (g/100g) of $M$. sanjappae bean (A-soaking, B-Autoclaving, C-Roasting, D-Soaking plus Autoclaving, ESoaking plus Roasting). Values are expressed as mean \pm SEM $(n=3)$ using oneway ANOVA followed by Dunnett's multiple comparison tests. $* * *=p<0.001$ when compared with Raw seed sample.

As L-DOPA also acts as an anti-nutritional factor, for the consideration of MS beans as a staple food, obliteration of L-DOPA is also important, and we found that soaking plus autoclaving is the excellent treatment for it.

\section{Effect of processing on nutritional value}

Results of proximate composition for the variously processed MS seeds are presented in Table 1. The protein level of MS bean is low $(6.327 \pm 0.2 \mathrm{~g} / 100 \mathrm{~g})$ as compared to $M$. pruriens and other cereal pulses $(18.5-27.87 \mathrm{~g} / 100 \mathrm{~g})$ (Siddhuraju and Becker, 2005; Costa et al., 2006; Mugendi et al., 2010). The protein content was significantly reduced due to the different processing $(\mathrm{p}<0.001)$. Process D (soaking plus autoclaving) decreases protein content

Table 1 Nutritional composition in raw and processed MS beans (g 100 / g dry matter) ${ }^{\mathrm{a}}$.

\begin{tabular}{|c|c|c|c|c|c|c|}
\hline & Raw Seed & $\mathbf{A}$ & B & $\mathrm{C}$ & D & $\mathbf{E}$ \\
\hline Ash & $5.83 \pm 0.74$ & $\begin{array}{l}5.45 \pm 0.92 \\
(6.51)\end{array}$ & $\begin{array}{c}4.92 \pm 0.672 \\
(15.60)\end{array}$ & $\begin{array}{c}5.39 \pm 0.25 \\
(7.54)\end{array}$ & $\begin{array}{c}4.28 \pm 0.263 * \\
(26.58)\end{array}$ & $\begin{array}{l}4.471 \pm 0.41 \\
\quad(23.31)\end{array}$ \\
\hline Total solid $^{\#}$ & $90.24 \pm 4.93$ & $\begin{array}{c}88.34 \pm 5.52 \\
(2.10)\end{array}$ & $\begin{array}{c}83.56 \pm 6.48 \\
(7.40)\end{array}$ & $\begin{array}{c}76.36 \pm 6.23 \\
(15.38)\end{array}$ & $\begin{array}{c}85.89 \pm 7.91 \\
(4.82)\end{array}$ & $\begin{array}{c}81.45 \pm 4.82 \\
(9.74)\end{array}$ \\
\hline Protein & $6.327 \pm 0.2$ & $\begin{array}{c}5.64 \pm 0.070 * * * \\
(10.85)\end{array}$ & $\begin{array}{c}4.99 \pm 0.048^{* * * *} \\
(21.13)\end{array}$ & $\begin{array}{c}5.591 \pm 0.078 * * * \\
(11.63)\end{array}$ & $\begin{array}{c}4.13 \pm 0.172 * * * \\
(34.72)\end{array}$ & $\begin{array}{c}4.731 \pm 0.148^{* * * *} \\
(25.22)\end{array}$ \\
\hline Total Carbohydrates & $77.23 \pm 0.757$ & $\begin{array}{c}46.232 \pm 0.04 * * * \\
\quad(40.13)\end{array}$ & $\begin{array}{c}49.036 \pm 0.056^{* * * *} \\
(36.50)\end{array}$ & $\begin{array}{c}47.22 \pm 0.096^{* * * *} \\
(38.85)\end{array}$ & $\begin{array}{c}43.88 \pm 0.28^{* * * *} \\
(43.18)\end{array}$ & $\begin{array}{c}42.48 \pm 0.064 * * * \\
\quad(44.99)\end{array}$ \\
\hline Reducing Sugar & $0.1252 \pm 0.003$ & $\begin{array}{c}0.0840 \pm 0.009 \\
(32.8)\end{array}$ & $\begin{array}{c}0.080 \pm 0.082 \\
(36)\end{array}$ & $\begin{array}{c}0.106 \pm 0.003 \\
\quad(15.2)\end{array}$ & $\begin{array}{c}0.096 \pm 0.005 \\
\quad(23.2)\end{array}$ & $\begin{array}{c}0.096 \pm 0.005 \\
(23.2)\end{array}$ \\
\hline Total Fat & $5.78 \pm 0.46$ & $\begin{array}{l}5.72 \pm 0.61 \\
(1.03)\end{array}$ & $\begin{array}{l}4.14 \pm 0.298^{*} \\
\quad(28.37)\end{array}$ & $\begin{array}{l}4.35 \pm 0.651 \\
(24.74)\end{array}$ & $\begin{array}{c}3.69 \pm 0.816^{* *} \\
(36.15)\end{array}$ & $\begin{array}{c}3.281 \pm 0.848 * * \\
\quad(43.25)\end{array}$ \\
\hline Starch & $3.82 \pm 0.72$ & $\begin{array}{c}3.27 \pm 0.189 \\
(14.39)\end{array}$ & $\begin{array}{l}2.75 \pm 0.478^{*} \\
(28.01)\end{array}$ & $\begin{array}{c}3.56 \pm 0.398 \\
(6.80)\end{array}$ & $\begin{array}{c}2.68 \pm 0.192 * \\
(29.84)\end{array}$ & $\begin{array}{l}2.53 \pm 0.223 * * \\
\quad(33.76)\end{array}$ \\
\hline Total Flavonoids & $20.327 \pm 0.854$ & $\begin{array}{c}16.916 \pm 0.590 * * \\
(16.78)\end{array}$ & $\begin{array}{c}6.706 \pm 0.598 * * * \\
(67)\end{array}$ & $\begin{array}{c}15.7781 \pm 0.449 * * * \\
(22.39)\end{array}$ & $\begin{array}{c}4.5777 \pm 0.370 * * * \\
(77.51)\end{array}$ & $\begin{array}{c}5.036 \pm 0.359 * * * \\
(75.22)\end{array}$ \\
\hline Proanthocyanidin & $1.89 \pm 0.098$ & $\begin{array}{c}1.56 \pm 0.15 \\
(17.46)\end{array}$ & $\begin{array}{c}1.08 \pm 0.22 * \\
(42.855)\end{array}$ & $\begin{array}{c}1.67 \pm 0.358 \\
(11.64)\end{array}$ & $\begin{array}{c}0.65 \pm 0.075^{* *} \\
(65.60)\end{array}$ & $\begin{array}{c}0.98 \pm 0.11^{*} \\
(48.14)\end{array}$ \\
\hline
\end{tabular}


$(4.13 \pm 0.172 \mathrm{~g} / 100 \mathrm{~g})$ by $34.72 \%$ while process A (soaking) showed the minima effect on protein level $(-10.85 \%)$. The decreased level of protein was also found in green gram and black gram due to soaking or cooking (Kakati et al., 2010). The total carbohydrate content of MS beans is high $(77.23 \pm 0.757 \mathrm{~g} / 100 \mathrm{~g})$ than M. pruriens (Kakati et al., 2010) which was reduced to $43.88 \pm 0.28$ and $42.48 \pm 0.064 \mathrm{~g} / 100 \mathrm{~g}(-43.88 \%$ and $-44.99 \%)$ through the

Process $\mathrm{D}$ and $\mathrm{E}$ respectively $(\mathrm{p}<0.001)$. MS bean has less reducing sugar $0.1252 \pm 0.003 \mathrm{~g} / 100 \mathrm{~g}$ which is lessened to $0.080 \pm 0.082 \mathrm{~g} / 100 \mathrm{~g}(-36 \%)$ during the autoclaving (Process B) ( $>>0.05)$. MS seed contained higher crude fat $(5.78 \pm 0.46$ $\mathrm{g} / 100 \mathrm{~g}$ ) than other legumes except for chickpea $(6.7 \mathrm{~g} / 100 \mathrm{~g})$ (Mugendi et al. 2010). Process $E$ (soaking plus roasting) found to be decreasing fat content to $3.281 \pm 0.848 \mathrm{~g} / 100 \mathrm{~g}(-43.25 \%)(\mathrm{p}<0.001)$. The starch content of raw MS bean was $3.82 \pm 0.72 \mathrm{~g} / 100 \mathrm{~g}$ which get decreased to $2.53 \pm 0.223 \mathrm{~g} / 100 \mathrm{~g}(-33.76 \%)$ $(\mathrm{p}<0.01)$ during the process $\mathrm{E}$ (soaking plus roasting). Process $\mathrm{C}$ (roasting) showed minimum effect on starch level $(-6.80 \%)(\mathrm{p}>0.05)$. It was found that the processing methods used in this study resulted in a reduction of the proximate nutritional level of the seeds. Protein and fat content does not decrease at significant level, but total carbohydrate showed an extreme loss due to processing.

Flavonoids are the important class of secondary metabolites having role in the treatment of oxidative stress related disorders like diabetes and Parkinsonism (Mu et al., 2009). MS bean showed a high content of flavonoids $(20.3279 \pm 1.48$ $\mathrm{g} / 100 \mathrm{~g}$ ) as compared to $M$. pruriens. A significant decrease in the flavonoid level was observed due to different processing techniques $(\mathrm{p}<0.001)$. Soaking and

roasting process (A and $\mathrm{C}$ respectively) lessen the amount of flavonoids up to $16.9160 \pm 1.02 \mathrm{~g} / 100 \mathrm{~g} \quad(-16.78 \%)$ and $15.7781 \pm 0.714 \mathrm{~g} / 100 \mathrm{~g} \quad(-22.39 \%)$ respectively. Process $\mathrm{B}, \mathrm{D}$, and $\mathrm{E}$ affected flavonoid content to a greater extent. Proanthocyanidin content of the raw seed sample was $1.89 \pm 0.17 \mathrm{~g} / 100 \mathrm{~g}$ which was decreased to $0.65 \pm 0.13 \mathrm{~g} / 100 \mathrm{~g}(-65.60 \%)(\mathrm{p}<0.01)$ due to the treatment of soaking plus autoclaving while the minimal reduction was found during the roasting treatment that is $1.67 \pm 0.62 \mathrm{~g} / 100 \mathrm{~g}(-11.64 \%)$. Several workers have reported the similar trend of reduction in nutritional factors and secondary metabolites due to the pretreatment in legumes and pulses (Kakati et al., 2010).

\section{Effect of processing on ANF content}

ANF commonly found in legume seeds and possesses the ability to chelates mineral cations and proteins, forming insoluble complexes, which lead to decreased bioavailability of trace minerals, reduced digestibility of proteins and inhibited proteolytic enzyme activity (Duodu and Minnaar, 1999). For the full utilization of legumes as food, deactivation or complete removal of antinutritional factors using economically viable techniques is required (Mugendi et al., 2010). Seed treatments under study are the simple, cheap and routinely used for the consumption of a leguminous plant food. The study showed that level of ANF is decreased during the processing of MS beans (Table 2).

Table 2 Anti-nutritional composition in raw and processed MS beans (g 100 / g dry matter)

\begin{tabular}{|c|c|c|c|c|c|c|}
\hline & Raw Seed & $\mathbf{A}$ & B & $\mathbf{C}$ & D & $\mathbf{E}$ \\
\hline L-DOPA & $10.81 \pm 0.24$ & $9.75 \pm 0.17 * * *(9.82)$ & $2.91 \pm 0.09 * * *(73.07)$ & $9.77 \pm 0.2 * * *(9.65)$ & $1.10 \pm 0.08 * * *(89.74)$ & $7.26 \pm 0.14 * * *(32.79)$ \\
\hline $\begin{array}{l}\text { Total } \\
\text { Phenolics }\end{array}$ & $11.11 \pm 0.45$ & $7.86 \pm 0.24 * * *(29.23)$ & $6.07 \pm 0.254 * * *(45.33)$ & $9.71 \pm 0.29 * * *(12.62)$ & $3.14 \pm 0.26 * * * 71.68)$ & $5.90 \pm 0.381 * * *(46.88)$ \\
\hline Phytic acid & $23.67 \pm 2.45$ & $18.82 \pm 1.56(20.48)$ & $14.89 \pm 3.26^{* *}(37.09)$ & $16.76 \pm 2.87 *(29.19)$ & $5.23 \pm 2.89 * * * 77.90)$ & $11.42 \pm 1.98 * * *(51.75)$ \\
\hline Tannin & $0.47 \pm 0.08$ & $0.30 \pm 0.01 * *(35.90)$ & $0.25 \pm 0.01 * * *(47.18)$ & $0.22 \pm 0.01 * * *(54.07)$ & $0.10 \pm 0.01 * * *(77.45)$ & $0.13 \pm 0.004 * * *(72.44)$ \\
\hline Saponin & $2.13 \pm 0.67$ & $1.74 \pm 0.82(18.64)$ & $1.42 \pm 0.37(33.08)$ & $1.54 \pm 0.18(27.83)$ & $0.92 \pm 0.12 *(56.88)$ & $1.16 \pm 0.44(45.64)$ \\
\hline
\end{tabular}

a. Values are expressed as mean \pm SEM $(n=3)$ using one-way ANOVA followed by Dunnett's multiple comparison test. * $\mathrm{p}<0.05$; $\quad * * \mathrm{p}<0.01 ; * * * \mathrm{p}<0.001$ when compared with Raw seed sample. A-soaking, B-Autoclaving, C-Roasting, D-Soaking plus Autoclaving, E-Soaking plus Roasting.Values in parentheses indicate the percent loss.

The phenolics content of the seed was $11.11 \pm 0.405 \mathrm{~g} / 100 \mathrm{~g}$ which gets significantly reduced to $3.147 \pm 0.263(-71.68 \%)$ during the process D (Soaking plus autoclaving) $(\mathrm{p}<0.001)$. Similar results were found in the treatment of faba beans (Siah et al., 2014). Phenolics reduce the digestion of protein, carbohydrates, and availability of vitamins and minerals (Mugendi et al., 2010) The MS seed showed a high amount of phytic acid $(23.67 \pm 2.45 \mathrm{~g} / 100 \mathrm{~g})$ as compared to other legumes (Embaby, 2011; Patil et al., 2015). Different processing methods reduce phytic acid at a considerable amount. Process D (soaking plus autoclaving) decreases its minimum level $5.23 \pm 2.89 \mathrm{~g} / 100 \mathrm{~g}$ ( $77.90 \%)(\mathrm{p}<0.001)$. We observed process A (soaking) has less effect on the phytic acid level $18.821 \pm 1.56 \mathrm{~g} / 100 \mathrm{~g}(\mathrm{p}>0.05)$. The reduction of phytic acid during soaking could be due to the presence of phytic acid in legume seed as a water-soluble salt (probably potassium phytate) (Khattab and Arntfield, 2009). Whereas, a decrease in phytic acid content during heat treatments may be because of the heat sensitive characteristic of phytic acid and its complex formed with other components (Khattab and Arntfield, 2009). Tannin and saponin level in the MS seed was $0.479 \pm 0.087$ and $2.134 \pm 0.67 \mathrm{~g} / 100 \mathrm{~g}$ respectively. These two factors also showed the same trend of decreasing the concentration by the combinational process soaking and autoclaving $(0.1085 \pm 0.01403(\mathrm{p}<0.001)$ and $0.92 \pm 0.124 \mathrm{~g} / 100 \mathrm{~g} \quad(\mathrm{p}<0.01)$ respectively). Tannin reduction due to such pretreatments is mainly credited to its water soluble and heat labile nature (Khattab and Arntfield, 2009)

All the processes under investigation affected proximate composition (nutritional and anti-nutritional factors) of the MS seed in varying degrees, but the process soaking plus autoclaving has a considerable effect. Overall, roasting (Process C) has less effect on the nutritional and ANF level, but it was evidenced to be effective in decreasing the amount of biomolecules in combination with autoclaving. Process A and B (soaking and autoclaving respectively) have shown effective processing methods, but the combination of both is more beneficial for reducing the level of ANF.

\section{Antioxidant potential of processed samples}

The effect of processing on the antioxidant capacity of MS beans was also determined. However, assessment of antioxidant capacity of plant sample could not be correctly achieved by any single method because of the diverse nature of phytochemicals present in it. Hence, we performed DPPH and FRAP assay for the determination of antioxidant activity of processed MS seeds. We observed that processing techniques reduces antioxidant properties of the MS beans.

\section{DPPH radical scavenging activity}

Figure 4 depicts the DPPH radical scavenging activity (DPPH RSA) of processed samples in comparison with raw beans sample. The water extract of raw bean sample showed $81.741 \pm 0.596 \%$ activity at the higher dose of $200 \mu \mathrm{g}$. DPPH radical scavenging activity was significantly reduced after the processing treatment $(\mathrm{p}<0.001)$ of MS seeds. The maximum decrease of $44.311 \pm 0.69 \%$ was observed during the process $\mathrm{D}$. The order of antioxidant activity was Raw $>B>A>C>E>D$. The response of DPPH radical scavenging activity for the differentially processed samples was decreased as compared to raw seed sample in which soaking plus autoclaving showed less DPPH radical scavenging capacity. Sweet and bitter Chenopodium quinoa seeds also showed decreased DPPH RSA in the due to boiling effect Dini et al., (2010).

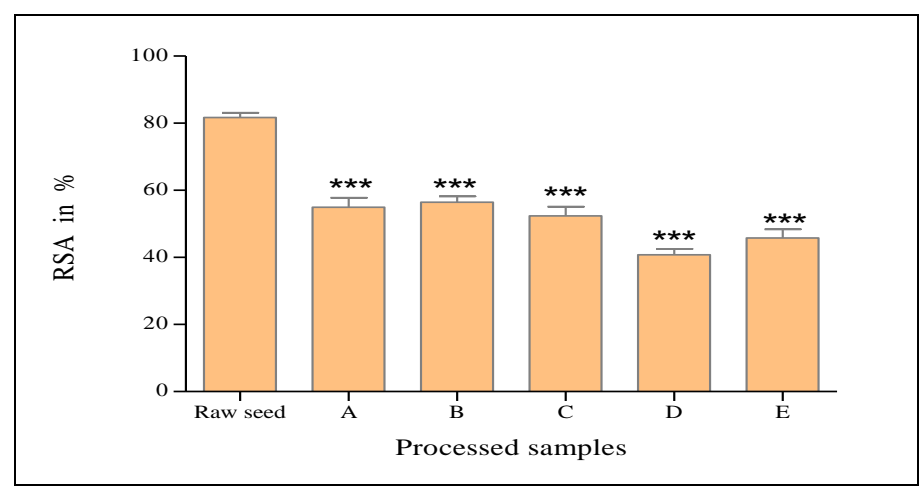

Figure 4 DPPH radical scavenging activity (\%) of different processed MS bean water extract (A-soaking, B-Autoclaving, C-Roasting, D-Soaking plus Autoclaving, E-Soaking plus Roasting). Values are expressed as mean \pm SEM $(n=3)$ using one-way ANOVA followed by Dunnett's multiple comparison tests. $* * *=\mathrm{p}<0.001$ when compared with Raw seed sample.

\section{FRAP radical scavenging activity}

The antioxidant potential of the processed bean samples was furthermore assessed using FRAP radical scavenging test (Fig 5). The results were determined in terms of optical density (O.D) at $593 \mathrm{~nm}$. The raw seed sample showed $3.353 \pm 0.17 \mathrm{O}$.D at the higher dose of $200 \mu \mathrm{g}$ indicating strong FRAP activity. There was no significant reduction in the FRAP activity of MS beans after processing ( $p>0.05)$. Highest decrease in activity (2.850 \pm 0.18 O.D.) was found for the treatment $\mathrm{D}$ (soaking plus autoclaving). The results suggest that 
processing of the seeds does not affect drastically on the FRAP radical scavenging activity. The order of activity was Raw $>\mathrm{A}>\mathrm{B}>\mathrm{E}>\mathrm{D}>\mathrm{C}$. Dini $\boldsymbol{e t}$ al. (2010) likewise found decreased FRAP activity in the sweet and bitter Chenopodium quinoa seeds due to boiling effect. Reduction in phenolic content and antioxidant activity of Chickpea (Cicer arietinum L.) has also been reported as an effect of soaking and cooking processes (Segev $\boldsymbol{e t}$ al., 2011).

The decreased level of antioxidant activity after the processing of MS seeds may be attributed to the structural changes or destruction of antioxidant biomolecules present in M. sanjappae seeds.

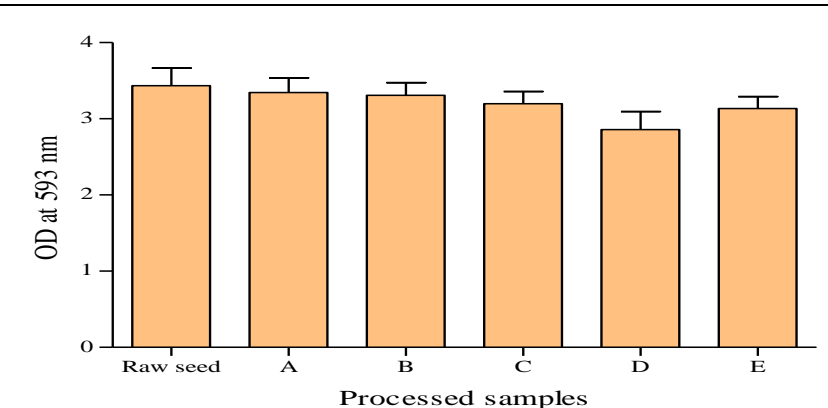

Figure 5. FRAP radical scavenging activity (O.D. at $593 \mathrm{~nm}$ ) of different processed MS bean water extract (A-Soaking, B-Autoclaving, C-Roasting, DSoaking plus Autoclaving, E-Soaking plus Roasting). Values are expressed as mean \pm SEM ( $\mathrm{n}=3$ ) using one-way ANOVA followed by Dunnett's multiple comparison tests.

\section{Effect of processing on anti-inflammatory activity}

Anti-inflammatory activity of plant based drug molecules is mainly depends on secondary metabolites present in it. Hence, it is worthwhile to study the influence of processing methods on the anti-inflammatory activity of MS seeds. This might be the first report showing processing effect on anti-inflammatory potential of leguminous plant.

\section{BSA anti-denaturation activity}

Figure 6 depicts the heat induced albumin denaturation activity of differentially processed MS seed. The raw bean sample showed $69.6 \pm 0.628 \%$ antidenaturation activity at the dose of $200 \mu \mathrm{g}$. The activity was considerably reduced after the processing treatment $(\mathrm{p}<0.001)$ of MS seeds. The maximum decrease of $33.2 \pm 0.8 \%$ was observed during the soaking plus autoclaving process. The order of BSA anti-denaturation activity was $\operatorname{Raw}>\mathrm{C}>\mathrm{A}>\mathrm{B}>\mathrm{E}>\mathrm{D}$. The reduction in activity suggests phytocompounds responsible for anti-inflammatory activity gets denatured or completely destroyed due to processing. Standard drug diclofenac showed $72.7 \pm 1.25 \%$ activity at the same concentration.

\section{Hypotonicity-induced hemolysis inhibition}

Study of anti-hemolysis activity is the representative assay of anti-inflammatory potential in drug molecule. Processed MS bean samples were analyzed for their hemolysis inhibition activity and found drastic effect on the activity (Fig 7). Raw sample showed $41.9 \pm 0.22 \%$ hemolysis inhibition (stabilization) activity for 200 $\mu \mathrm{g}$ extract concentration. The lowest stabilization activity was observed in the soaking plus autoclaving and soaking plus frying process (26.8 \pm 0.72 and $26.8 \pm 0.2 \%$ respectively).

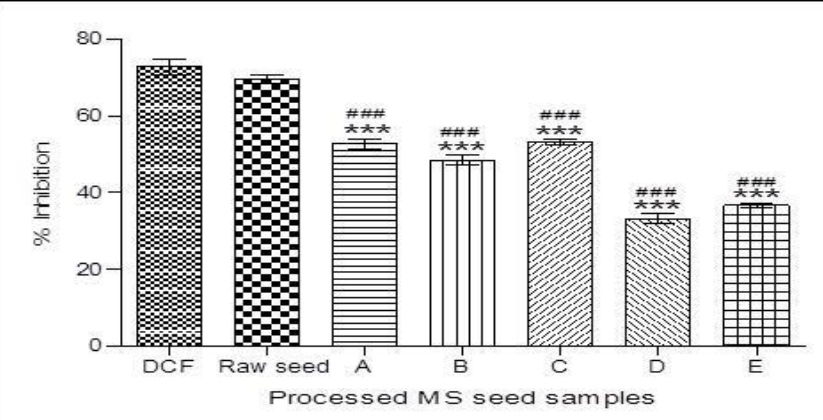

Figure 6 BSA anti-denaturation activity assay of different processed MS bean (A-soaking, B-Autoclaving, C-Roasting, D-Soaking plus Autoclaving, E-Soaking plus Roasting). Values are expressed as mean \pm SEM $(n=3)$ using one-way ANOVA followed by Dunnett's multiple comparison tests. ${ }^{* * *}=\mathrm{p}<0.001$ when compared with Raw seed sample.

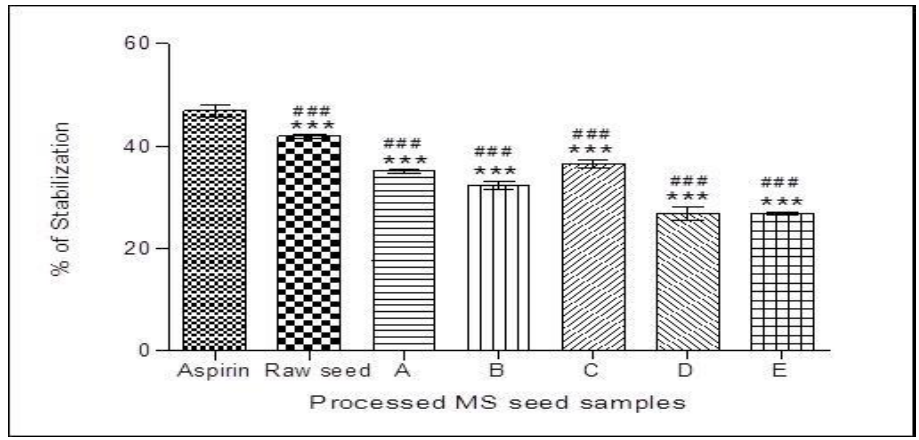

Figure 7 Human Red Blood Cell (HRBC) membrane stabilization activity (\%) of different processed MS bean (A-soaking, B-Autoclaving, C-Roasting, D-Soaking plus Autoclaving, E-Soaking plus Roasting). Values are expressed as mean \pm SEM $(\mathrm{n}=3)$ using one-way ANOVA followed by Dunnett's multiple comparison tests. $* * *=p<0.001$ when compared with Raw seed sample.

Standard drug aspirin showed $46.78 \pm 0.7 \%$ stabilization activity at the same concentration. Decrease in hemolysis inhibition property in processed MS seed indicates partial denaturation or complete destruction of phytocompounds responsible for it.

\section{CONCLUSIONS}

M. sanjappae has tremendous scope for exploring as a functional food due to its anti-Parkinson's drug L-DOPA and higher level of antioxidants content. From the present study, it can be conclude that, amongst the various processing treatments, soaking plus autoclaving is the most efficient treatment for reducing the L-DOPA and other anti-nutrients. The processing methods also affect nutritional constituents, antioxidants and anti-inflammatory potential. The processing techniques under study are easy and cost effective which can provide an easy way of processing MS bean to utilize its full potential as a functional food. This study will be helpful to explore M. sanjappae as a novel source of food to world as demand is continuously increasing due to increasing population.

Acknowledgements: Prof Jyoti Jadhav thanks to Department of Biotechnology, Govt. of India for funding through DBT-IPLS program (Ref. No. BT/PR4572/INF/22/147) sanctioned to Department of Biotechnology, Shivaji University, Kolhapur, India. Mr. Ravishankar Patil acknowledges SUK-DBT IPLS program and National Post-Doctorate Fellowship funded by SERB, (DST) India for providing fellowship. Govind Vyavahare thanks, Shivaji University for providing scholarship through DRS scheme. Mr. Chetan Aware acknowledges SUK-DBT IPLS program for the fellowship. Prof. Vishwas Bapat is thankful to Indian National Science Academy, New Delhi, India for senior scientist fellowship.

\section{CONFLICT OF INTEREST}

The authors declare no conflicts of interest.

\section{REFERENCES}

Aitawade, M., and Yadav S. (20120029. Mucuna sanjappae, a new species from the north-Western Ghats, India. Kew Bulletin, 67, 539-543. https://doi.org/10.1007/s12225-012-9369-1

AOAC. (1990). Official methods of analysis, 15th edn. Association of Official Analytical Chemists, Washington. https://doi.org/10.1016/0165-9936(90)87098-7 AOAC. (2000). Official methods of analysis of the association of the analytical chemists, Int'l 17th edn. AOAC International, Gaithersburg.https://www.chemicalbook.com/ChemicalProductProperty EN CB 72096013.html

Benzie, I., and Strain, J. (1996). The ferric reducing ability of plasma (FRAP) as a measure of "antioxidant power": the FRAP assay. Analytical Biochemistry, 239, 70-76. DOI: $10.1006 /$ abio. 1996.0292

Bhurat, M., and Sapakale, H. (2011). Preliminary chemical evaluation and in vitro anti-inflammatory activity of leaves of Remusatia vivipara. Asian Journal of Biochemical and Pharmaceutical Research, 2, 303-306.

Bishnoi, S., Khetarpaul, N., and Yadav, R. (1994). Effect of domestic processing and cooking methods on phytic acid and polyphenol contents of pea cultivars (Pisum sativum). Plant Foods for Human Nutrition, 45, 81-388. https://link.springer.com/article/10.1007/BF01088088

Brand-Williams, W., Cuvelier, M., and Berset, C. (1995). Use of free radical method to evaluate antioxidant activity. Lebensmittel-Wissenschaft and Technologie, 28, 25-30. https://doi.org/10.1016/S0023-6438(95)80008-5

Carsky, R., Tarawali, S., Bercker, N., Chikoya, D., Tian, G. and Sagina, N. (1998). Мисиna - herbaceous cover legume with potential for multiple uses. Resource and Crop Management Research Monograph No. 25, International Institute of Tropical Agriculture, Ibadan, Nigeria. pp. 54. 
Chang, C., Yang, M., Wen, H. and Chern, J. (2002). Estimation of total flavonoid content in propolis by two complementary colorimetric methods. Journal of Food and Drug Analysis, 10, 178-182.

Chau, C., and Cheung, P. (1997). Effect of various processing methods on antinutrients and in vitro digestibility of protein and starch of two Chinese indigenous legume seeds. Journal of Agricultural and Food Chemistry, 45, 4773 4776.

https://doi.org/10.1111/j.1745-4514.2008.00199.x

Costa, G., Queiroz-Monici, K., Smpm, R., and Oliveira, A. (2006). Chemica composition, dietary fiber and resistant starch contents of raw and cooked pea, common bean, chickpea and lentil legumes. Journal Food Biochemistry, 94, 327 330. https://doi.org/10.1016/j.foodchem.2004.11.020

Dini, I., Tenore, G., and Dini, A. (2010). Antioxidant compound contents and antioxidant activity before and after cooking in sweet and bitter Chenopodium quinoa seeds. LWT Food Science and Technology,43,447-451. https://doi.org/10.1016/j.lwt.2009.09.010

Duodu, K., and Minnaar, J. (1999). Effect of cooking and irradiation on the labile vitamins and antinutrient content of a traditional African sorghum porridge and spinach relish. Food Chemistry, 66, 21-27. https://doi.org/10.1016/S0308 8146(98)00070-3

Embaby, H. (2011). Effect of heat treatments on certain antinutrients and in vitro protein digestibility of peanut and sesame seeds. Food Science and Technology Research, 17, 31-38.

https://doi.org/10.3136/fstr.17.31

Gao, Y., Shang, C., Maroof, S., and Buss, G. (2007). A modified colorimetric method for phytic acid analysis in soybean. Crop Science, 47, 1797-1803. https://doi.org/10.2135/cropsci2007.03.0122

Grant, N., Alburn, H., and Kryzanauskas, C. (1969). Stabilization of serum albumin by anti-inflammatory drugs. Biochemical Pharmacology, 19, 715-722 https://doi.org/10.1016/0006-2952(70)90234-0

Harborne, J., (1973). Phytochemical methods. Chapman and Hall, Ltd, London, pp 49-188.

James, C., (1995). Analytical chemistry of food. Seale-Hayne Faculty of Agriculture, Food and Lane use Department of Agriculture and Food studies University of Polymouth, UK. 1, 96-97. https://doi.org/10.1007/978-1-46152165-5

Kakati, P., Deka, S., Kotoki, D., and Saikia, S. (2010). Effect of traditiona methods of processing on the nutrient contents and some antinutritional factors in newly developed cultivars of green gram [Vigna radiata (L.) Wilezek] and black gram [Vigna mungo (L.) Hopper] of Assam, India. International Food Research Journal, 17, 377-384.

Khattab, R., and Arntfield, S. (2009). Nutritional quality of legume seeds as affected by some physical treatments 2. Antinutritional factors. LWT- Food $\begin{array}{llll}\text { Science and } & \text { Technology, } & \text { 1113-1118 }\end{array}$ https://doi.org/10.1016/j.lwt.2009.02.004

Kirk, H., and Sawyer, R. (1998). Frait pearson chemical analysis of food, vol 8 Longman Scientific and Technical, Edinburgh, pp 211-212.

Lampariello, L., Cortelazzo, A., Guerranti, R., Sticozzi, C., Valacchi G. (2012) The Magic Velvet Bean of Mucuna pruriens. Journal of Traditional and Complementary Medicine, 2(4), https://www.ncbi.nlm.nih.gov/pmc/articles/PMC3942911/

Liener, I. (1994). Antinutritional factors related to proteins and amino acids. Foodborne disease handbook $3^{\text {rd }}$ vol. (New York: Marcel Dekker) pp. 261-309.

Lowry, O., Rosbrough, N., Farr, A., and Randall, R. (1951). Protein measurement with the Folin phenol reagent. Journal of Biological Chemistry, 193, 265-275. http://www.jbc.org/content/193/1/265.full.pdf

Mccready, R., Guggolz, J., Silviera, V., and Owens, A. (1950). Determination of starch and amylose in vegetables. Analytical Chemistry, 22, 156-1158. https://doi.org/10.1021/ac60045a016

Miller, G. (1959). Use of dinitrosalicylic acid reagent for determination of reducing sugar. Analytical Chemistry, 31, 426-428 https://doi.org/10.1021/ac60147a030

Mu, X., He, G., Yuan, X., Li, X. and Du, G. (2009). Baicalein exerts neuroprotective effects in 6-hydroxydopamine-induced experimental Parkinsonism in vivo and in vitro. Pharmacology Biochemistry and Behavior, 92 642-648. https://doi.org/10.1016/j.pbb.2009.03.008

Mugendi, J., Njag, Enm., Kuria, E., Mwasaru, M., Mureithi, J. and Apostolides, Z. (2010). Effects of processing technique on the nutritional composition and anti-nutrient content of Mucuna bean (Mucuna pruriens L.). African Journal of Food Science, 4, 156 -166. http://hdl.handle.net/2263/16076

Nielsen, S. (1991). Digestibility of legume protein: studies indicate that the digestibility of heated legume protein is affected by the presence of other seed components and the structure of the protein. Food Technology 45, 112-114.

Nyirenda, D., Musukwa, M., and Jonsson, L., (2003). The effects of different processing methods of velvet beans (Mucuna pruriens) on L-dopa content, proximate composition and broiler chicken performance. Tropical and $\begin{array}{llll}\text { Subtropical } & \text { Agroecosystems, } & \text { 253-260 }\end{array}$ http://www.redalyc.org/articulo.oa?id=93911288026
Osei-Bonsu, P., Buckles, D., Soza, F. and Asibuo, J. (1995). Traditional food uses of Mucuna pruriens and Canavalia ensiformis in Ghana. ILEIA newsletter, 12, 30-31

Patil, R., Gholave, A., Yadav, S., Bapat, V., and Jadhav, J. (2015). Mucuna sanjappae Aitawade et Yadav: a new species of Mucuna with promising yield of anti-Parkinson's drug L-DOPA. Genetic Resources and Crop Evolution, 62, 55162

https://doi.org/10.1007/s10722-014-0164-8

Patil, R., Pawar, K., Rane, M., Yadav, S., Bapat, V. and Jadhav, J. (2016) Assessment of genetic diversity in Mucuna species of India using randomly amplified polymorphic DNA and inter simple sequence repeat markers. Physiol Mol Biol Plants, 22, 207-217. https://doi.org/10.1007/s12298-016-0361-3

Rathod, B., and Patel, N. (2014). Development of validated RP-HPLC method for the estimation of L-Dopa from Mucuna pruriens, its extracts and in Aphrodisiac formulation. International Journal of Pharma Sciences and Research, 5, 508-513.

Sadique, J., Al-Rqobahs, W., Bughaith, M. and El-Gindi, A. (1989). The bioactivity of certain medicinal plants on the stabilization of RBC membrane system. Fitoterpia, 60, 525-32.

Segev, H., Badani, H., Galili, L., Hovav, R., Kapulnik, Y., Shomer, I., and Galili, S. (2011). Total phenolic content and antioxidant activity of chickpea (Cicer arietinum L.) As affected by soaking and cooking conditions. Food and Nutrition Sciences, 2, 724-730.

https://doi.org/10.4236/fns.2011.27099

Siah, S., Wood, J., Agboola, S., Konczak, I., and Blanchard, C. (2014). Effects of soaking, boiling and autoclaving on the phenolic contents and antioxidan activities of faba beans (Vicia faba L.) differing in seed coat colors. Food Chemistry, $142,461-468$

https://doi.org/10.1016/j.foodchem.2013.07.068.

Siddhuraju, P. and Becker, K. (2001). Effect of Various Domestic Processing Methods on Antinutrients and in Vitro Protein and Starch Digestibility of Two Indigenous Varieties of Indian Tribal Pulse, Mucuna pruriens var. utilis. Journal of Agricultural and Food Chemistry, 49 (6), 3058-3067. https://doi.org/10.1021/jf001453q

Siddhuraju, P., and Becker, K. (2005). Nutritional and antinutritional composition, in vitro amino acid availability, starch digestibility and predicted glycemic index of differentially processed mucuna beans (Mucuna pruriens var. utilis): an under-utilised legume. Food Chemistry, 91, 275-286. https://doi.org/10.1016/j.foodchem.2004.02.044

Singleton, V., and Rossi, J. (1965). Colorimetry of total phenolics with phosphomolybdic-phosphotungstic acid reagents. American Journal of Enology and Viticulture, 16, 144-158.

Sun, B., Ricardo-Da-Silva, J., and Spranger, I. (1998). Critical factors of vanillin assay for catechins and proanthocyanidins. Journal of Agricultural and Food Chemistry, 46, 4267-4274. https://doi.org/10.1021/if980366i

Thaipong, K., Boonprakob, U., Crosby, K., Cisneros-Zevallos, L., and Hawkins Byrne, D. (2006). Comparison of ABTS, DPPH, FRAP and ORAC assays for estimating antioxidant activity from guava fruit extracts. Journal of Food $\begin{array}{llll}\text { Composition and } & \text { Analysis, } & \text { 669-675 }\end{array}$ https://doi.org/10.1016/j.jfca.2006.01.003

Tharanathan, R., and Mahadevamma, S. (2003). Grain legumes-A boon to human nutrition. Trends in Food Science \& Technology, 14, 507-518. https://doi.org/10.1016/j.tifs.2003.07.002

Tiansawang, K., Luangpituksa, P., Varanyanond, W., and Hansawasdi, C. (2016) GABA ( $\gamma$-aminobutyric acid) production, antioxidant activity in some germinated dietary seeds and the effect of cooking on their GABA content. Food Science and Technology, 36, 313-321.

http://dx.doi.org/10.1590/1678-457X.0080

Trevelyan, W., Forrest, R., and Harrison, J. (1952). Determination of yeast carbohydrates with the anthrone reagent. Nature, 170, 626-627.

Vadivel V and Pugalenthi M. (2008). Effect of various processing methods on the levels of antinutritional constituents and protein digestibility of Mucuna pruriens (L.) Dc. var. utilis (wall. Ex wight) baker ex burck (velvet bean) seeds. Journal of Food Biochemistry, 32, 795-812. https://doi.org/10.1111/j.1745 4514.2008.00199.x

Wilmot-Dear, C. (1986). Revision of Mucuna (Leguminosae:Phaseoleae) in the Indian Subcontinent and Burma. Kew Bulletin, 42, 23-46. https://doi.org/10.2307/4109895

Wilmot-dear, C. (1991). A revision of Mucuna (Leguminosae-Phaseoleae) in the Philippines. Kew Bulletin, 46, 213-251. https://doi.org/10.2307/4110591 